\title{
Effectiveness of E-banking during COVID 19 Pandemic
}

\author{
Ms. Vruti Chavda \\ Working as Assistant Teacher, N.G. Junior college of commerce (NSM degree college), \\ Vile Parle (East) Mumbai400057
}

\begin{abstract}
Covid 19 virus developed in the year 2019 and rapidly spread across the world by close contact of infected person of COVID 19 virus. WHO and most of the countries including India declared pandemic. E-banking has become a boon for the society in this covid19 pandemic. It is easily accessible through internet facility in smart phones, computer, laptop, tablet and so on. E-banking has played an effective role during COVID 19 pandemic by operating completely electronically without exchange of tangible commodities to protect the people and maintain social distance. People are feeling completely safe and easily accessible in online transactions (like payments of necessary items(food and medicine), bills, recharge, investment, transferring fund, receiving payments, etc.) Therefore, the purpose of this research is to search and examine the effectiveness of E-banking during pandemic.
\end{abstract}

Keywords: COVID 19, Internet Banking, Online, Bank, E-banking , Effectiveness, Banking Transactions

\section{INTRODUCTION:}

The present world is unified with expanding on the web admittance to administrations. One piece of this which is growing rapidly is E-banking. E-banking is otherwise called Electronic banking or Internet banking. Web based banking permits a client to manage monetary exchanges by means of the Internet. Internet banking offers clients pretty much every help customarily accessible through a nearby office including stores, moves, and online bill instalments.

During the Covid19 situation the Government has announced a lockdown from March 2020 to August 2020. Because of this the greater part of the organizations and associations are shut and a large portion of them lost their positions. Be that as it may, banks were permitted to work with restricted staff and in specific regions. Along these lines, individuals can't come out for their customary requirements for banking and they think that it is troublesome and the banks request that their clients utilize internet banking administrations. Hence, the need for E-banking has increased during the covid19 situation and the Reserve Bank of India (RBI) said that $57 \%$ of the customers are using online banking. The banks were concentrated more on online banking for the better experience and satisfaction of the customers.

As per wellbeing proposals, one of the best approaches to contain the current COVID-19 pandemic is to keep away from individual contact. This implies decreasing the development of individuals and expanding the time they spend at home however much as could reasonably be expected. In accordance with these signs, most banks in the influenced nations have decreased the opening times of their branches and they suggest their clients utilize web based banking. To energize the utilization of this channel, many banks have made a move to convey positive messages and to help their clients to remember the advantages of internet banking. These advantages incorporate the simplicity of completing any exchange all day, every day and appreciating super durable admittance to all monetary data continuously. A few banks have additionally attempted to advance internet banking by sharing instructional exercises and growing the kinds of exchanges clients can do distantly.

Customary banking has declined during the COVID-19, and thusly, expansion in e-banking stages is noticed. Thus, the empirical potential to evaluate the banking services is needed to understand the behavioural changes. Electronic banking constructed a productive progression of administrations furnished with diminished functional and fixed expenses with more security highlights joined.

\section{AIMS AND OBJECTIVES:}

The main purpose of this study is to evaluate the effectiveness of e-banking environment in Covid-19 pandemic. In order to meet this objective, the following objectives taken up under consideration.

- To find out the effective factors of e-banking facilitation to customer services

- To enhance online services and meet beyond the expectations

- $\quad$ To contribute in useful direction during Covid -19

- $\quad$ To maintain social distance and avoid close contacts 
Vol. 10, Issue 10, October 2021

DOI: $10.17148 /$ IJARCCE.2021.101001

\section{SCOPE OF THE STUDY:}

This review gives a manual for the current design of the Internet banking security and features mindfulness level of clients for utilizing Internet banking, and their discernment and fulfilment towards Internet banking with new technologies and its functioning. This helps to know in details about development in banking industry with advancement in technology. It likewise helps in understanding various administrations presented in Internet banking. Eventually this would help in understanding the advantages of Internet banking to clients just as banking industry.

\section{REVIEW OF LITERATURE:}

- Joseph and Stone (2003) investigated the customer perception of the impact of technology on service delivery in the banking sector. According to the findings of this research, high scores on the ability to deliver service via technology appear to be correlated with high satisfaction with services deemed most important to customers.

- (Hassan et al., 2012) The purpose of this study is to find out the determinants that mainly affect the customer service quality perception of internet banking amongst genders and different age groups. The research found that Web design, security, trust, product diversification, credibility, collaboration, access and communication strongly affect the customer perception about the quality of internet banking service.

- $\quad$ Dhrupad, M., et al (2014). This examination gives a knowledge of client impression of innovation based financial assistance quality in a creating nation. These components were confirmation, responsiveness, usability, availability, satisfaction, speed and exactness, and contact. The outcomes show that occasional estimations of the degrees of internet banking administration quality should turn into a basic aspect of any bank's exertion and procedure in improving help quality levels.

\section{RESEARCH METHODOLOGY:}

Research Methodology is a specific procedure or technique used to identify, select, process and analyse information about a topic. In research paper, the approach segment permits the peruse to assess a general learn about the theme. The examination philosophy assists us with getting an answer for an issue. It expects to give the work plan of exploration.

\section{PRIMARY DATA:}

In this review, the essential information was gathered through organized polls with different measures. A structured questionnaire had few multiple-choice questions. In this review, the essential information was gathered through organized polls with different measures. A structured questionnaire was used to collect responses through convenience sampling. The responses were measured on a 5-point Likert scale ranging from Poor (1) to Excellent (5). Online link was sent to different people for survey. A total 108 responses were received.

This research was limited to Mumbai e-banking environment because of accessibility issue of respondents and time constraint as quick research is needed and appreciated in these unprecedented times.

\section{DATA ANALYSIS:}

\begin{tabular}{|c|c|c|}
\hline Category & No. of Responses & $\%$ \\
\hline 1. Gender & $\begin{array}{l}\text { Male: } 44 \\
\text { Female: } 64\end{array}$ & $\begin{array}{l}\text { Male: } 41.1 \% \\
\text { Female : } 59.3 \%\end{array}$ \\
\hline Age & $\begin{array}{l}\text { 18-36: } 79 \\
\text { 37-56: } 27 \\
\text { 56\&above: } 2\end{array}$ & $\begin{array}{l}\text { 18-36: } 73.1 \% \\
\text { 37-56: } 25.2 \% \\
\text { 56\&above: } 1.9 \%\end{array}$ \\
\hline Level of Education & $\begin{array}{l}\text { Under Graduate: } 12 \\
\text { Graduate : } 55 \\
\text { Post Graduate : } 36 \\
\text { Above PG: } 5\end{array}$ & $\begin{array}{l}\text { Under Graduate: } 11.2 \% \\
\text { Graduate : } 50.9 \% \\
\text { Post Graduate }: 33.6 \% \\
\text { Above PG: } 4.7\end{array}$ \\
\hline Usage of E-banking & $\begin{array}{l}\text { No usage : } 6 \\
\text { Rarely : } 24 \\
\text { Frequently : } 78\end{array}$ & $\begin{array}{l}\text { No usage }: 5.5 \% \\
\text { Rarely : } 22.2 \% \\
\text { Frequently }: 72.2 \%\end{array}$ \\
\hline Convenient & $\begin{array}{l}\text { Poor: } 2 \\
\text { Fair : } 12 \\
\text { Satisafactory: } 54 \\
\text { Very good: } 16\end{array}$ & $\begin{array}{l}\text { Poor: } 1.8 \% \\
\text { Fair : } 11.1 \% \\
\text { Satisafactory: } 50 \% \\
\text { Very good: } 14.8 \%\end{array}$ \\
\hline
\end{tabular}


Vol. 10, Issue 10, October 2021

DOI: $10.17148 /$ IJARCCE.2021.101001

\begin{tabular}{|c|c|c|}
\hline & Excellent : 24 & Excellent : $22.2 \%$ \\
\hline $\begin{array}{l}6 . \quad \text { Effectiveness of E- } \\
\text { banking }\end{array}$ & $\begin{array}{l}\text { Poor: } 1 \\
\text { Fair : } 12 \\
\text { Satisafactory: } 53 \\
\text { Very good: } 22 \\
\text { Excellent : } 20\end{array}$ & $\begin{array}{l}\text { Poor: } 0.92 \% \\
\text { Fair : } 11.1 \% \\
\text { Satisafactory: } 49.07 \% \\
\text { Very good: } 20.37 \% \\
\text { Excellent : } 18.51 \%\end{array}$ \\
\hline
\end{tabular}

RESULT:

The survey had a larger ratio of female (59.3\%) as compare to male (41.1\%)

\section{Gender}

108 responses

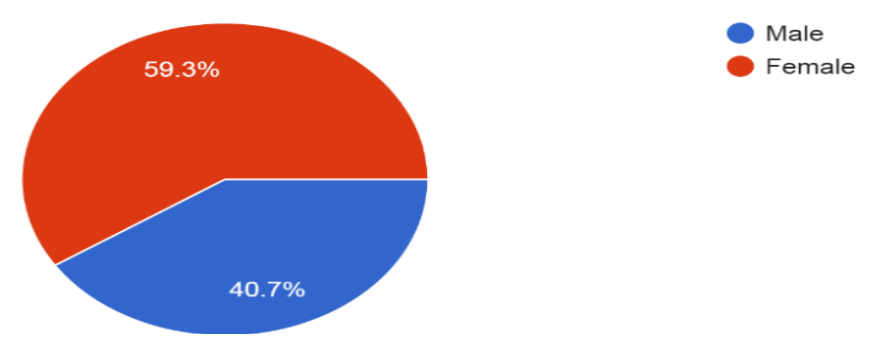

Most of them (79) were young adults, with an age range 18-36 years, which makes $73.1 \%$ of the total followed by 27 respondents with age range $37-56$ years. The least (2) were in the age range $57 \&$ above years.

Age
108 responses
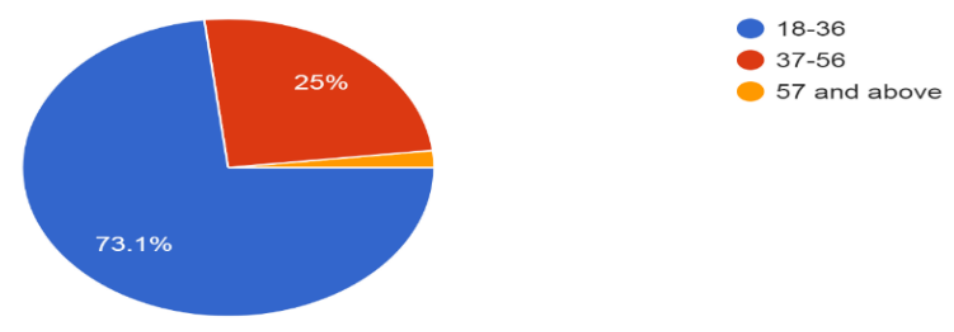

Majority of respondents are Graduate (59.9\%) followed ug (11.2\%) followed pg (33.6\%) followed other (4.7\%)

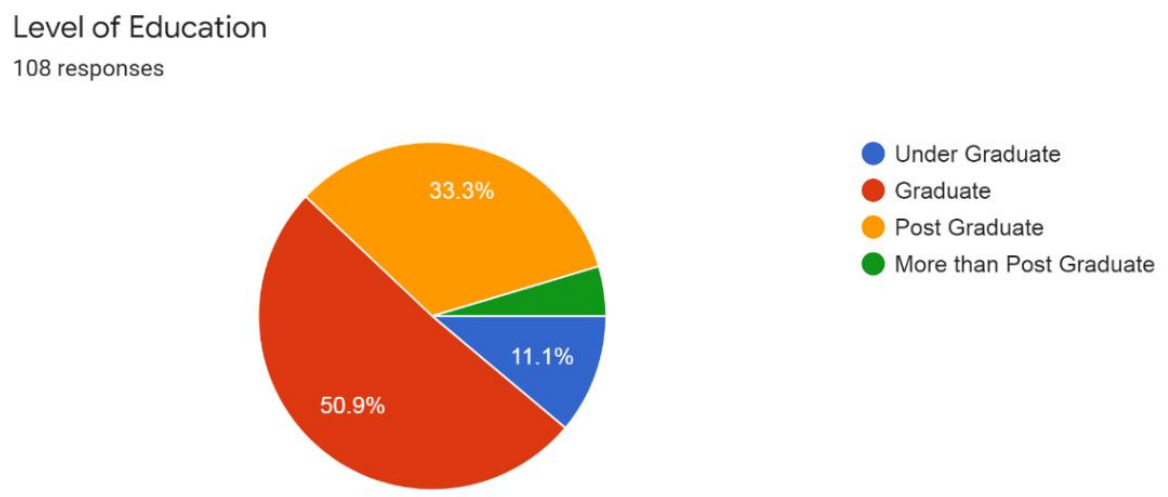


Most of respondents frequently uses e-banking platform and nearly $72 \%$ believed e-banking is more useful than the conventional banking particularly because of lockdown restrictions, time and cost effectiveness.

Usage of E-banking

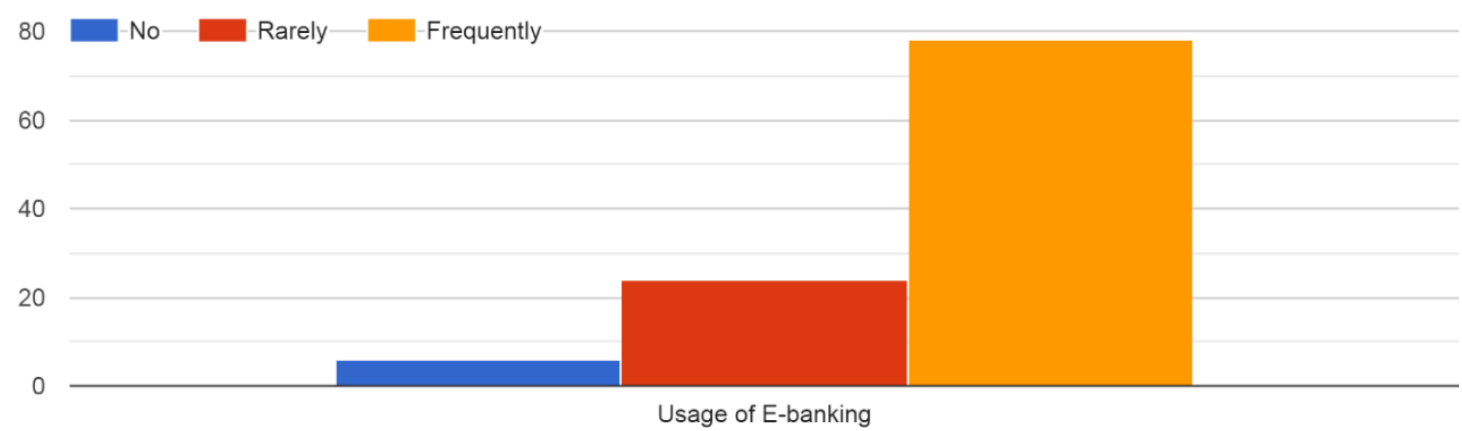

\section{BENEFITS OF E-BANKING:}

- $\quad 24 / 7$ account and service access

- $\quad$ Speed and efficiency

- $\quad$ Online bill payment

- $\quad$ Low overhead can mean low fees

- Low overhead can mean high interest rates on deposit accounts

- Moving towards Paperless Society

\section{LIMITATION OF E-BANKING}

- Technology issues

- Security issues

- Inefficient at complex transactions

- $\quad$ No relationship with personal banker

- $\quad$ Safety situations around ATMs.

\section{E-BANKING-SERVICE}

E-banking/Online banking providing various services and making life easier and safer on our fingertip during this pandemic.

Services are as under:

$\begin{array}{ll}\text { - } & \text { Bill Payment Service } \\ \text { - } & \text { Fund Transfer } \\ \text { - } & \text { Credit Card Customers } \\ \text { - } & \text { Railway, Airway Tickets } \\ \text { - } & \text { Investing through Internet Banking } \\ \text { - } & \text { Recharging your Prepaid Phone } \\ \text { - } & \text { Shopping at your fingertips } \\ & \text { School/College Fees }\end{array}$

\section{SUGGESTION:}

This study was conducted not only to identify the Effectiveness of E-banking during COVID 19 but also to identify the usage and Convenience of Online banking in Pandemic. Though many of the respondent have started using E-banking facilities during Covid 19 but they are finding difficult to operate. Some of the respondent are not satisfied with the online services. Some of them are facing loyalty, security issues. Bank needs to improve their Online banking facilities as well as security of online transactions to attract more and more people towards E-banking. So, customers can find easy to access the Internet Banking facilities and also find E-banking effective. 


\section{CONCLUSION:}

The current circumstances progress the requirement of E-banking, had a critical influence on the usage of conventional banking and focused on the influence during the pandemic.

We have considered only the effectiveness of E-banking during COVID 19 Pandemic from the point of view of customers.

Further research also can empirically on effectiveness of E-banking from the point of view of bank and can consider banks data from multiple nations.

\section{REFERENCES:}

1. Quach, T.N., Thaichon, P. and Jebarajakirthy, C. (2016), "Internet service providers' service quality and its effect on customer loyalty of different usage patterns", Journal of Retailing and Consumer Services, Vol. 29, pp. 104-113.

2. Rovetta, A. and Bhagavathula, A.S. (2020), "Covid-19-related web search behaviors and infodemic attitudes in italy: infodemiological study", JMIR Public Health and Surveillance, Vol. 6 No. 2, pp. e19374.

3. Santouridis, I. (2009), "E-Service quality and its impact on customer satisfaction and trust: an empirical study on Greek customers of internet shops", Paper presented at the Proceedings of the 6th International Conference on Enterprise Systems, Accounting and Logistics, Hessaloniki, Greece.

4. Shankar, A. and Jebarajakirthy, C. (2019), “The influence of e-banking service quality on customer loyalty", International Journal of Bank Marketing, Vol. 37 No. 5.

5. Chaudhry, I.G., Abbas, Q., Awan, T.M. and Ghafoor, A. (2009), "Trust, satisfaction and E-Loyalty in Pakistan's electronic commerce", Paper presented at the e-CASE 2019 - International Conference on e-Commerce, e-Administration, e-Society, and e-Education, Singapore.

6. Foroughi, B., Iranmanesh, M. and Hyun, S.S. (2019), "Understanding the determinants of mobile banking continuance usage intention", Journal of Enterprise Information Management, Vol. 32 No. 6.

7. Giao, H., Vuong, B. and Quan, T. (2020), "The influence of website quality on consumer's e-loyalty through the mediating role of e-trust and esatisfaction: an evidence from online shopping in Vietnam”, Uncertain Supply Chain Management, Vol. 8 No. 2, pp. 351-370.

8. Hall, M.C., Prayag, G., Fieger, P. and Dyason, D. (2020), "Beyond panic buying: consumption displacement and COVID-19”, Journal of Service Management.

9. Liang, C.-C. and Pei-Ching, W. (2015), "Internet-banking customer analysis based on perceptions of service quality in Taiwan", Total Quality Management and Business Excellence, Vol. 26 No. 5-6, pp. 550-568. XJM 17,1/2 52

10. Rovetta, A. and Bhagavathula, A.S. (2020), "Covid-19-related web search behaviors and infodemic attitudes in italy: infodemiological study", JMIR Public Health and Surveillance, Vol. 6 No. 2, pp. e19374.

11. Sahu, P. (2020), "Closure of universities due to coronavirus disease 2019 (COVID-19): impact on education and mental health of students and academic staff", Cureus, Vol. 12 No. 4.

12. Lang, Bodo and Colgate, Mark (2003), Relationship Quality, On-Line Banking and The Information Technology Gap. International Journal of Bank Marketing, 21(1), 29-37.

13. Sraeel, H. (1996). Creating real value propositions with virtual banking', Bank Systems and Technology, 33(8), 6-8

14. Wu, J., Hsia, T. and Heng, M.S. (2006). Core capabilities for exploiting electronic banking', Journal of Electronic Commerce Research, 7(2),111-123.

15. 15. Southard, P.B. and Siau, K. (2004). A survey of online e-banking retail initiatives. Communications of the ACM, 47(10), 99-102. 